\title{
Role of different Culicoides vectors (Diptera: Ceratopogonidae) in bluetongue virus transmission and overwintering in Sardinia (Italy)
}

Cipriano Foxi ${ }^{1}$, Gavino Delrio ${ }^{1}$, Giovanni Falchi ${ }^{1}$, Maria Giovanna Marche ${ }^{1}$, Giuseppe Satta ${ }^{2}$ and Luca Ruiu ${ }^{1 *}$

\begin{abstract}
Background: Bluetongue (BT) epidemics have affected the Mediterranean island of Sardinia since 2000. While Culicoides imicola represents the main bluetongue virus (BTV) vector, other European Culicoides biting midges, possibly implicated in virus transmission, have been detected here. Understanding their distribution, seasonal abundance, and infection rates is necessary to predict disease incidence and spread across coastal and inland areas, and to define their role in virus overwintering.

Methods: Biting midge abundance was determined by light traps on selected farms representing diverse climatic conditions of Sardinia. Livestock-associated Culicoides species were morphologically and molecularly identified. Infection rates in prevailing midge species captured in 2013 during a BTV-1 outbreak were determined using RTqPCR based virus detection in insect body pools, supplemented by specific body region analyses. The seasonal infection prevalence in Culicoides samples collected in 2001 in a BTV-2 affected farm was also determined.

Results: The Newsteadi complex (C. newsteadi species A and species B) prevailed among all biting midge species (47.7\%), followed by C. imicola (27.8\%) and the Obsoletus complex (C. obsoletus and C. scoticus) (17.6\%). Whilst Culicoides imicola was more abundant along the coast, the Newsteadi complex was frequently collected at higher altitude and the Obsoletus complex was notably associated to cattle farms. Culicoides pulicaris and C. punctatus abundance was found to be marginal in all farms. BTV was detected in parous female samples of all these species, and the full dissemination of the virus within the body of C. imicola, C. obsoletus, C. scoticus, and Newsteadi complex species was confirmed by analyses of thorax and head, containing salivary glands. Higher infection rates were associated with C. scoticus, C. newsteadi species A and species B, compared to C. imicola. The virus was detected in C. newsteadi species A and C. obsoletus in winter and spring, whereas it was mainly found in summer and autumn in C. imicola.
\end{abstract}

Conclusions: In Sardinia, bluetongue virus is transmitted by multiple Culicoides vectors, including C. imicola and the Newsteadi complex being the most important. The Newsteadi complex and other midge species can play an important role in internal areas and are likely to be directly involved in virus overwintering.

Keywords: Bluetongue, BTV, Virus detection, Virus overwintering, Biting midges, Culicoides vectors, Seasonal abundance, Infection rate

\footnotetext{
* Correspondence: lucaruiu@uniss.it

'Dipartimento di Agraria, University of Sassari, Via E. De Nicola, Sassari, Italy

Full list of author information is available at the end of the article
} 


\section{Background}

With nearly 1,350 worldwide distributed species (at least 117 in Europe), the genus Culicoides (Diptera: Ceratopogonidae) is characterized by a significant diversity of biting midges [1] whose hematophagous females can transmit a variety of filarial worms, protozoans and arthropod-borne viruses to man and wild or domestic animals [2]. Bluetongue virus (BTV), which includes at least 27 different serotypes so far identified [3, 4], is the etiological agent of the internationally significant bluetongue (BT) disease that affects feral and farmed ruminants, and is among the viruses transmitted by these insect pests of medical and veterinary importance in Europe [5].

Insect vectors play a main role in BTV circulation among ruminants, although minor events of host to host transmission are possible through secondary routes including transplacental, iatrogenic and direct contact mechanisms. [6] BTV transmission is mainly carried out by Culicoides biting midges that acquire the virus through ingestion of blood from viraemic vertebrate hosts [2]. After infecting susceptible Culicoides females, the arbovirus replicates in midgut cells, reaches the salivary glands and is consequently transmitted through further biting activities on animal hosts [7]. Only parous females that have completed a gonotrophic cycle are able to transmit the virus via subsequent blood meals, over their remaining life span. Vector susceptibility and BTV infection are genetically heritable traits that depend on several factors, such as Culicoides species/population and virus strain [8], but it is also influenced by extrinsic factors such as temperature [9]. Despite the huge diversity within the genus Culicoides, only around 30 species have been associated with BTV transmission [10].

BTV vector competence was demonstrated by laboratory infection studies only for few Culicoides species including C. sonorensis, C. imicola, C. obsoletus and C. scoticus [11]. However, vector competence can also be evaluated through virus detection and quantification in field-collected Culicoides midges. In fact, the direct detection of BTV in the head and thorax, due to the lack of salivary gland infection barriers, could indicate successful virus dissemination in the body of these insects [12]. Moreover, evidence of virus replication in parous females can also be demonstrated by the detection of high virus genome load in their body [13]. In line with this approach, Culicoides and BTV diagnostic technologies based on modern Real-time Quantitative Reverse TranscriptionPolymerase Chain Reaction (RT-qPCR) may allow the separation of individuals with sub-transmissible infections from the fully disseminated ones, as demonstrated in laboratory assays with C. sonorensis [14]. In Europe, potential vector species were identified from studies based on virus isolation or detection by RT-qPCR in field-collected parous females [15-21], detection of virus dissemination in field individuals [13], and arboviral infection in laboratory assays [22-24]. Consequently, C. imicola, C. obsoletus and $C$. scoticus are presently considered as confirmed BTV vectors, while $C$. chiopterus, $C$. dewulfi, C. pulicaris and C. punctatus as probable vectors [25].

Since 2000, Sardinia, an Italian island located in the middle of the Mediterranean basin, has been affected by BTV serotypes $1,2,4,8$ and 16 . The most severe epidemics occurred in 2000-2001 (BTV-2) and in 2013-2014 (BTV-1 and 4), resulting in the loss of more than 500,000 [26] and 100,000 sheep [27] of an approximately 3.5 million total population, respectively. These two main epidemics persisted for two consecutive years, demonstrating the ability of the virus to overwinter in this environment.

In Sardinia, Culicoides fauna comprises at least 45 species, of which only few are mammalophilic and livestock-associated. These include the confirmed BTV vectors, C. imicola, C. obsoletus and C. scoticus, that belong to the subgenus Avaritia, and the probable vectors C. pulicaris (s.l.), C. punctatus and two genetically distinct species of the Newsteadi complex, included within the subgenus Culicoides [28, 29]. BTV-1 was detected by RT-qPCR in field-collected parous females of all these species during 2012-2013 epidemics [30]. Another larger study, conducted in different Italian regions during BTV-1 and BTV-4 outbreaks in 2012-2014, confirmed virus positivity for the same vector species and, additionally, for C. montanus and $C$. dewulfi. Remarkably, high virus genome loads were detected in pools of $C$. newsteadi (s.l.) from southern Italy, which substantiates the potential role of this species in transmitting BTV during these outbreaks [31].

Based on this information, it is clear that there are different vectors potentially contributing to BTV transmission in Europe. However, for the successful spread of the disease, a vector species not only has to be virus-competent, but it should also be significantly abundant along with an adequate biting rate and host preference within a specific ecosystem [32]. However, information on the actual vector capacity of Culicoides species are still insufficient and specific studies on their distribution and abundance in diverse environments characterized by BTV epidemics are needed. In addition, virus overwintering mechanisms in different areas of the world still need to be elucidated. Recent studies from Sardinia reported high abundance of C. obsoletus, C. scoticus, and C. newsteadi (s.l.) populations in winter (and not C. imicola), implicating these species [28,33].

To help close this gap, we studied distribution, abundance and seasonality of Culicoides species involved in BTV transmission in relation to climatic factors and the availability of blood meal sources. These investigations 
included RT-qPCR-based virus detection and infection rate determination in field-collected midge species from livestock farms affected by BTV epidemics in 2012-2013 and, retrospectively, in 2000-2001.

Through comparative analyses of different Culicoides species distribution, seasonal abundance, and infection rates, we examined their actual role in transmission and overwintering of the virus in coastal and internal areas of Sardinia, which generated awareness on the dynamics of potential vectors in a specific ecosystem. The scalability of this study model to a variety of Mediterranean environments will allow implementing more appropriate disease risk analyses and effective integrated vector management measures.

\section{Methods}

\section{Study area}

Studies were conducted in Sardinia, a region with a typical Mediterranean climate where winter is mild with rare freezing temperatures along the coast and summer is hot and dry with day temperatures often exceeding $30{ }^{\circ} \mathrm{C}$. Although the inland summer temperatures are high, the winter temperatures frequently drop below zero degrees. The island receives most rainfall during October-April, on an average 400-600 $\mathrm{mm}$ along the coast and 500-800 mm inland, respectively per year.

A total of ten farms, representing different climatic conditions of Sardinia and differently stocked with animals, were involved in this study (Table 1).

\section{Culicoides midge collection}

Adult Culicoides were collected using suction light traps (miniature blacklight trap; GZ International, Ferrara, Italy) fitted with a blacklight tube (Philips TL $4 \mathrm{~W} / 08$ ) and a downdraught suction motor. Traps, operating overnight from dusk until dawn of the following day, were hung $1.8 \mathrm{~m}$ above the ground inside an open shelter in six farms and outside a shelter close to the livestock in the other four farms.

Trapping was carried out once a week in Sassari-1 during 2001, in Fonni during 2003, and at other seven sites during 2008. In the case of Bari Sardo, weekly captures were limited to the period April-July 2013, during a major BTV outbreak.

Table 1 Characteristics of the 10 farms where Culicoides midges were collected by light traps in Sardinia

\begin{tabular}{|c|c|c|c|c|c|c|c|c|}
\hline $\begin{array}{l}\text { Collection } \\
\text { sites }\end{array}$ & $\begin{array}{l}\text { Geographic } \\
\text { coordinates (sites } \\
\text { ranked North to } \\
\text { South) }\end{array}$ & $\begin{array}{l}\text { Altitude } \\
\text { (m asl) }\end{array}$ & $\begin{array}{l}\text { Mean low } \\
\text { temperature of } \\
\text { the coldest } \\
\text { month }\left({ }^{\circ} \mathrm{C}\right)\end{array}$ & $\begin{array}{l}\text { Mean high } \\
\text { temperature of } \\
\text { the warmest } \\
\text { month }\left({ }^{\circ} \mathrm{C}\right)\end{array}$ & $\begin{array}{l}\text { Annual } \\
\text { precipitation } \\
(\mathrm{mm})\end{array}$ & $\begin{array}{l}\text { Host } \\
\text { diversity } \\
\text { and host } \\
\text { abundance }\end{array}$ & $\begin{array}{l}\text { Trap } \\
\text { localisation }\end{array}$ & Main larval habitats \\
\hline Arzachena & $41^{\circ} 09^{\prime} \mathrm{N} ; 9^{\circ} 23^{\prime} \mathrm{E}$ & 77 & 3.60 & 33.10 & 800 & 200 sheep & $\begin{array}{l}\text { outside sheep } \\
\text { shelter, close to } \\
\text { sheep }\end{array}$ & $\begin{array}{l}\text { leaking watering troughs, } \\
\text { permanent puddles, water } \\
\text { spring }\end{array}$ \\
\hline Sassari-1 & $40^{\circ} 45^{\prime} \mathrm{N} ; 8^{\circ} 12^{\prime} \mathrm{E}$ & 120 & 5.16 & 30.70 & 460 & 500 sheep & $\begin{array}{l}\text { inside sheep } \\
\text { shelter, widely } \\
\text { open }\end{array}$ & $\begin{array}{l}\text { cattle-watering pond, } \\
\text { shallow pool, leaking } \\
\text { watering troughs, manure }\end{array}$ \\
\hline Sassari-2 & $40^{\circ} 44^{\prime} \mathrm{N} ; 8^{\circ} 12^{\prime} \mathrm{E}$ & 140 & 5.23 & 31.80 & 600 & $\begin{array}{l}50 \text { cattle; } 10 \\
\text { horses; } 300 \\
\text { sheep }\end{array}$ & $\begin{array}{l}\text { inside sheep } \\
\text { shelter, widely } \\
\text { open }\end{array}$ & $\begin{array}{l}\text { cattle-watering pond, } \\
\text { shallow pool, manure }\end{array}$ \\
\hline Olmedo & $40^{\circ} 38^{\prime} \mathrm{N} ; 8^{\circ} 22^{\prime} \mathrm{E}$ & 30 & 2.13 & 31.37 & 600 & 250 sheep & $\begin{array}{l}\text { inside sheep } \\
\text { shelter, widely } \\
\text { open }\end{array}$ & $\begin{array}{l}\text { natural drainage channel, } \\
\text { leaking watering troughs }\end{array}$ \\
\hline Fonni & $40^{\circ} 07^{\prime} \mathrm{N} ; 9^{\circ} 18^{\prime} \mathrm{E}$ & 980 & -2.66 & 32.33 & 810 & 100 sheep & $\begin{array}{l}\text { outside sheep } \\
\text { shelter, close to } \\
\text { sheep }\end{array}$ & $\begin{array}{l}\text { natural drainage channel, } \\
\text { sheep-watering pond }\end{array}$ \\
\hline Seneghe & $40^{\circ} 03^{\prime} \mathrm{N} ; 8^{\circ} 32^{\prime} \mathrm{E}$ & 160 & 5.90 & 34.00 & 500 & $\begin{array}{l}60 \text { cattle; } 250 \\
\text { sheep }\end{array}$ & $\begin{array}{l}\text { inside cattle } \\
\text { barn, with little } \\
\text { openings }\end{array}$ & $\begin{array}{l}\text { leaking watering troughs, } \\
\text { natural drainage channel, } \\
\text { manure }\end{array}$ \\
\hline Barisardo & $39^{\circ} 81^{\prime} \mathrm{N}^{\prime} 9^{\circ} 65^{\prime} \mathrm{E}$ & 50 & 3.73 & 31.03 & 650 & 300 sheep & $\begin{array}{l}\text { outside sheep } \\
\text { shelter, close to } \\
\text { sheep }\end{array}$ & leaking watering troughs \\
\hline Lanusei & $39^{\circ} 52^{\prime} \mathrm{N} ; 9^{\circ} 33^{\prime} \mathrm{E}$ & 490 & 1.00 & 30.83 & 500 & 100 goats & $\begin{array}{l}\text { outside, closed } \\
\text { to goats }\end{array}$ & leaking watering troughs \\
\hline Villaverde & $39^{\circ} 48^{\prime} \mathrm{N} ; 8^{\circ} 47^{\prime} \mathrm{E}$ & 450 & 2.85 & 33.30 & 500 & 350 sheep & $\begin{array}{l}\text { inside sheep } \\
\text { shelter, widely } \\
\text { open }\end{array}$ & $\begin{array}{l}\text { natural drainage channel, } \\
\text { leaking watering troughs, } \\
\text { sheep-watering pond }\end{array}$ \\
\hline S. Antioco & $38^{\circ} 59^{\prime} \mathrm{N} ; 8^{\circ} 25^{\prime} \mathrm{E}$ & 40 & 7.93 & 33.13 & 500 & 50 cattle & $\begin{array}{l}\text { inside cattle } \\
\text { barn, widely } \\
\text { open }\end{array}$ & $\begin{array}{l}\text { leaking watering } \\
\text { troughs, manure }\end{array}$ \\
\hline
\end{tabular}




\section{Identification of Culicoides midge species}

Biting midges were initially identified to species or complex level according to wing pigmentation patterns of both sexes and male genital morphology, using different keys [34-36]. Additional morphometric and molecular analyses were conducted for females of Obsoletus, Pulicaris, and Newsteadi complexes, to differentiate known species.

For Obsoletus complex identification, including $C$. obsoletus (s.str.) and C. scoticus, the terminal half part of female abdomen was dissected and mounted on glass slides for microscopic observations. The remaining insect body portion was used for molecular analysis based on ITS2 rDNA amplification and sequencing [37] and on species-specific PCR assays targeting COI gene [38]. The following morphometric characters of the abdomen were measured: length between the chitinous plates, length and width of larger and smaller spermathecae $[39,40]$. All specimens that were submitted to viral detection assays were also identified by molecular analysis, while representative samples (10-20\%) of females, collected monthly from 6 sites, were identified by morphometric analysis, in order to derive the proportion of C. obsoletus and C. scoticus in each farm, thus allowing significant cost savings.

Since sibling species belonging to the Pulicaris complex were recently identified through molecular analysis [29, 41-44], after being morphologically identified, $C$. pulicaris (s.l.) samples were submitted to species-specific PCR assays based on mitochondrial cytochrome $c$ oxidase subunit I (COI) gene amplification [38].

To identify species belonging to the Newsteadi complex, both molecular and morphological analysis were conducted. Midges were preliminarily distinguished into two forms based on wing pattern and additional morphometric characters (i.e. separation of eyes and palpal segment size): (i) form $\mathrm{A}$, with wider and less pigmented wings showing small and diffused pale spots at the tip of vein $\mathrm{M}_{1}$ and $\mathrm{M}_{2}$; and (ii) form $\mathrm{B}$, with smaller and more pigmented wings with well-defined, clear pale spots at the tip of $M_{1}, M_{2}$ and $C_{1}$ veins. Subsequent analyses of the ribosomal internal transcribed spacer 2 (ITS2 rDNA) sequences were performed to confirm the reliability of these morphological characters to discriminate between C. newsteadi species A and B, as previously detected in Sardinia [29]. Recent morphometric and molecular investigations on the Newsteadi complex have led to the identification of different species in diverse geographical areas of Europe [29, 38, 41, 42, 44, 45]. To verify correlation between $C$. newsteadi N1, N2, and N3 from Catalonia, Spain [41] and C. newsteadi species A and B, we analyzed our samples with species-specific PCR assays targeting COI gene.

The females of all species were age-graded according to the abdominal pigmentation [46] and small pools
( $\leq 10$ specimens) of parous females, after identification procedures, were kept in ethanol $(70 \%)$ at $4{ }^{\circ} \mathrm{C}$ until being used for BTV detection analyses.

\section{Detection of BTV infection of Culicoides midges}

Analyses for BTV detection were based on total RNA extraction from pools of parous females belonging to different Culicoides species from the same site and date of capture, followed by retro-transcription to cDNA and qPCR with serotype-specific primers targeting BTV genome segment 2 [3].

Insect pools were routinely washed in PBS and transferred into $1.5 \mathrm{ml}$ Eppendorf tubes containing $700 \mathrm{ul}$ Trizol $^{\circ}$ Reagent (Life Technologies, USA) and $200 \mu \mathrm{l}$ of 1-mm-diameter zirconia beads, and homogenized in a Tissue Lyser LT (Qiagen, Hilden, Germany) [47]. cDNA was synthesized using SuperScript ${ }^{\mathrm{tm}}$ II Reverse Transcriptase (RT) (Life Technologies, USA) in compliance with the manufacturer's instructions. Subsequently, cDNA was amplified by PCR with 1A2 for BTV-1 and 2A1 for BTV-2 primer pairs under conditions described in Maan et al. [3]. Samples were provisionally considered positive with the virus when an amplified product of the predicted size was observed on an agarose gel. For confirmation, some of the bands of interest were excised from the gel and amplicons purified using a QIAquick gel extraction kit (Qiagen, Hilden, Germany) for sequencing. Output sequences were analyzed by NCBI Basic Local Alignment Search Tool http://www.ncbi.nlm.nih.gov/blast/Blast.cgi. For quantitative purposes, all positive samples were further analyzed by real-time RT-qPCR assay using the SuperScript ${ }^{\text {ti }}$ III One-Step RT-PCR System with Platinum ${ }^{\odot}$ Taq High Fidelity in compliance with the manufacturer's instructions and in accordance with a standardized assay [48]. Amplification was carried out in an Applied Biosystems 7900HT Fast Real-Time PCR System and fluorescence was measured at the end of the $60{ }^{\circ} \mathrm{C}$ annealing/extension step. Cycle threshold $(\mathrm{Ct})$ values for each sample were determined when a threshold fluorescence line was breached. Insect pools with a cycle threshold $(\mathrm{Ct})$ value $<30$ were confirmed as BTV positive.

Culicoides species involved in virus detection analyses were collected during spring and summer 2013 in a BTV-1 affected sheep farm located in Bari Sardo [49]. This investigation involved 1,622 parous females grouped into 163 species-specific pools including all the livestock-associated Culicoides species in Sardinia. According to preliminary studies demonstrating an efficient detection of the virus by RT-qPCR on a single infected midge, pool size was limited to 10. All analyses were generally conducted on the full insect body, except for C. obsoletus and C. scoticus whose terminal part of 
abdomen was previously employed for identification purposes.

To confirm the full dissemination of the virus in BTV positive species, additional RT-qPCR analyses were conducted to detect the virus in head and thorax regions of small pools (5 individuals) of parous females of C. imicola, C. obsoletus, C. scoticus and C. newsteadi species A and B. The remaining abdominal region was used for genetic discriminations among species of Obsoletus and Newsteadi complexes. Culicoides pulicaris (s.str.) and C. punctatus were not included in these analyses because of the lack of a sufficient number of positive specimens.

A retrospective BTV infection prevalence survey was also conducted on ethanol-stored Culicoides midges captured in the Sassari-1 farm, during a BTV-2 outbreak in 2001. This investigation had the specific purpose of establishing virus prevalence in Culicoides species over the year. Analyses were carried out on monthly collected parous females grouped in 68 species-specific pools of $C$. imicola, C. obsoletus and C. newsteadi species A and B.

\section{Statistical analysis}

Association between Culicoides species abundance and collection sites in 2008 was assessed by Pearson's Chisquare $\left(\chi^{2}\right)$ test using $\mathrm{R}$ software with significance level set at $\alpha=0.05[50]$.

The minimum infection rates (expressed per 1,000 parous females) in prevailing midge species collected during BTV-1 outbreak in 2013 were calculated using PooledInfRate software [51].

\section{Results}

Distribution, abundance and seasonality of livestockassociated Culicoides midges

A total of 140,624 Culicoides adults (131,783 females and 8,841 males) belonging to 15 different species were collected during 441 survey nights by traps placed in ten different livestock farms in Sardinia. All farms included diverse Culicoides larval habitats that were mostly associated with leaking drinking troughs, watering ponds, natural drainage channels, and manure heaps (Table 1). The majority of midge adults (134,305 specimens) represented species normally associated with animals and known to be proven or potential BTV vectors in the Mediterranean region: C. imicola, Obsoletus complex (C. obsoletus and C. scoticus), C. pulicaris (s.l.), C. punctatus, and Newsteadi complex (C. newsteadi species A and B). With the sole exception of $C$. imicola that was not found in the farm at higher altitude, all the other species were detected in varying proportions in each farm (Table 2 and Fig. 1), with a significant dependence between species and site of collection (Pearson's Chisquare test: $\left.\chi^{2}=56767.59, d f=24, P<0.001\right)$.
The Newsteadi complex prevailed over other midge species, representing $47.7 \%$ of the whole population of potential vectors collected during the study period in different farms. Within this complex, C. newsteadi species $\mathrm{A}$ and $\mathrm{B}$, identified through molecular analysis, were reliably distinguished also by wing pattern examination. Species-specific PCR assays targeting COI gene, showed a significant correspondence between $C$. newsteadi species A from Sardinia and N1 from Catalonia [41]. Culicoides newsteadi species A and B were both detected in every farm, with varying ratios. In detail, species $A$ prevailed (60-96 \%) in four farms located at lower altitude in northern Sardinia, while species B was more common (63-96 \%) in farms based in the centralsouthern part of the island, excluding a farm in Villaverde (450 m asl) with just $6 \%$. Culicoides imicola was the second most captured species representing $27.8 \%$ of the whole midge collection. The distribution of this species was remarkably comparable to Newsteadi complex species, showing prevalence in farms along the coast of Sardinia. However, C. imicola was never or hardly ever collected in farms above $450 \mathrm{~m}$ asl, whereas the Newsteadi complex showed more ecological flexibility, being captured even at $980 \mathrm{~m}$ asl. Obsoletus complex species accounted for $17.6 \%$ of total midges, but were the most abundant in three farms where they reached $30 \%$. Two species of this complex, C. obsoletus and $C$. scoticus, were molecularly and morphologically identified. As a result of morphometric measurements on molecularly identified females, the following individual morphological discontinuities were found: larger spermatheca (length range 68-79 and width range 45$55 \mu \mathrm{m}$ for $C$. scoticus; length range 44-50 and width range $34-38 \mu \mathrm{m}$ for $C$. obsoletus) and smaller spermatheca (length range 59-77 and width range 44-54 $\mu \mathrm{m}$ for C. scoticus; length range 46-49 and width range 34$37 \mu \mathrm{m}$ for $C$. obsoletus). On the other hand, overlapping was observed for length between the chitinous plates of these species. Both species were reported in six different sampling sites, with general predominance of C. scoticus, accounting for $70 \%$ of the whole catch. The abundance of Pulicaris complex, accounting for $7.8 \%$ of total midge collection, was significant only in two farms and it was the predominant species at $980 \mathrm{~m}$ asl. Molecular analysis confirmed that the specimens from Bari Sardo used in virus detection analyses were C. pulicaris (s.str.) [38, 41, 42]. This species was also detected in samples from locations with higher capture (Fonni and Seneghe). However, this molecular confirmation was not available for all samples and further studies on Pulicaris complex in Sardinia are needed. For this reason, C. pulicaris (s.l.) was used in abundance and distribution data analysis. Besides, C. punctatus was detected in all farms, but was the less represented species, amounting to just $1.1 \%$ of total midge captures. 
Table 2 Relative numbers of Culicoides species collected one night per week by light traps in Sardinia

\begin{tabular}{lllllllllll}
\hline Collection sites & Year & $\begin{array}{l}\text { Total } \\
\text { Culicoides }\end{array}$ & C. imicola & $\begin{array}{l}\text { Obsoletus } \\
\text { complex }\end{array}$ & C. obsoletus & C. scoticus & $\begin{array}{l}\text { C. newsteadi } \\
\text { species A }\end{array}$ & $\begin{array}{l}\text { C. newsteadi } \\
\text { species B }\end{array}$ & $\begin{array}{l}\text { C. pulicaris (s.l.) } \\
\text { C. } \\
\text { punctatus }\end{array}$ \\
\hline Arzachena & 2008 & 25506 & 5615 & $892^{\mathrm{b}}$ & - & - & 9479 & 6320 & 175 & 184 \\
Sassari 1 & 2001 & 12356 & 3919 & 87 & 74 & 13 & 5255 & 277 & 35 & 13 \\
Sassari 2 & 2008 & 11166 & 9317 & 140 & 94 & 46 & 1327 & 58 & 4 & 7 \\
Olmedo & 2008 & 8204 & 2334 & $363^{\mathrm{b}}$ & - & - & 2011 & 132 & 15 & 181 \\
Fonni & 2003 & 8919 & 0 & $895^{\mathrm{b}}$ & - & - & 316 & 193 & 6062 & 287 \\
Seneghe & 2008 & 33548 & 4150 & 1433 & 281 & 1152 & 8467 & 14350 & 1728 & 277 \\
Bari Sardo & 2013 & 15162 & 5948 & 5559 & 185 & 5374 & 103 & 2776 & 77 & 77 \\
Lanusei & 2008 & 4819 & 525 & 2102 & 1366 & 736 & 6 & 42 & 480 & 46 \\
Villaverde & 2008 & 3761 & 6 & $182^{\mathrm{b}}$ & - & - & 1075 & 69 & 201 & 71 \\
S. Antioco & 2008 & 17183 & 3286 & 6053 & 2361 & 3692 & 1759 & 4958 & 4 & 69 \\
\hline
\end{tabular}

${ }^{\mathrm{a} C a p t u r e s}$ between April-July

${ }^{\mathrm{b}}$ Obsoletus complex species were not distinguished

The amount of midges collected by traps in each farm, during different years, allowed to adequately define a detailed seasonal abundance pattern for adults and parous females of six different Culicoides species. Seasonal dynamics in farms, representative of a Northern and a Southern location selected on the basis of the highest catches of each species, were obtained by calculating a three-week moving average of the raw count data. This was carried out in order to reduce spurious temporal changes in abundance due to variation in meteorological conditions during the weekly trapping effort (Fig. 2) [52]. The seasonal abundance of $C$. newsteadi species A and $B$ did not differ within the same farm, and adults were captured by light traps throughout the year displaying 3 marked population peaks in spring, summer and autumn (Arzachena, 2008). Generally, the maximum abundance was reached during June-August; however, in the case of the southern farm (Sant'Antioco, 2008), $C$. newsteadi species B was more abundant in FebruaryMay. Parous females of the Newsteadi complex were collected throughout the year and represented, on average, $35 \%$ of total females collected, with whom they shared the same seasonal trend. Culicoides imicola was never or rarely captured during the first five months of the year, which was followed by a rapid population increase starting from July and reaching the peak in summer-autumn (Sassari-2, 2008). In the southern farm (Sant'Antioco, 2008), an earlier population growth was recorded in April. The number of parous females represented $45 \%$ of total females. Culicoides scoticus was detected during the whole year with 3-4 population peaks depending on the farm, and was generally more abundant during the first or the last months of the year (Seneghe and Sant'Antioco, 2008). In the southern farm, parous females collected during February-April accounted for $66.5 \%$ of the entire year collection, and in the same period their number per trap/night ranged between 14 and 71, respectively. Similarly, C. obsoletus was detected over the whole year, but the highest density was recorded during summer (Lanusei and Sant'Antioco, 2008). Culicoides pulicaris showed four abundance peaks during April-November, while its abundance during the first months of the year was very low (Fonni, 2003; Seneghe, 2008). The majority of adults were collected in April in the $980 \mathrm{~m}$ asl site. The abundance peaks for parous females ( $26 \%$ of total females) were similar to those recorded for the total female population.

\section{Detection of BTV infection of Culicoides midges}

BTV-1 was significantly detected in 63 out of 163 species-specific pools of biting midges collected during an outbreak between April and July 2013 in Bari Sardo. Among these, 35 (21.5\%) and 17 (10.4\%) carried a high (Ct range: $25-30)$ and a very high $(\mathrm{Ct}<25)$ virus genome load, respectively. The higher loads were found in pools of C. imicola, C newsteadi species A and B, and C. scoticus parous females, that represented the majority of pools analyzed during this period. Culicoides obsoletus, C. pulicaris and C. punctatus, collected from April to May, were represented in only a few female pools analyzed, but were also found to be BTV-1 positive ( $\mathrm{Ct}$ range: 25-30) (Table 3).

The results of RT-qPCR for the detection of the virus in specific parous female body regions (head and thorax) confirmed the full dissemination of BTV within the main midge vectors. Higher virus genome loads were found in head and thorax of C. scoticus and C. newsteadi species A, and in thorax of C. imicola and C. newsteadi species B (Table 4).

The minimum infection rates (MIRs), expressed per 1,000 parous females, has been calculated for the prevailing midge vectors for which a sufficient number of samples was available. Culicoides scoticus had the 


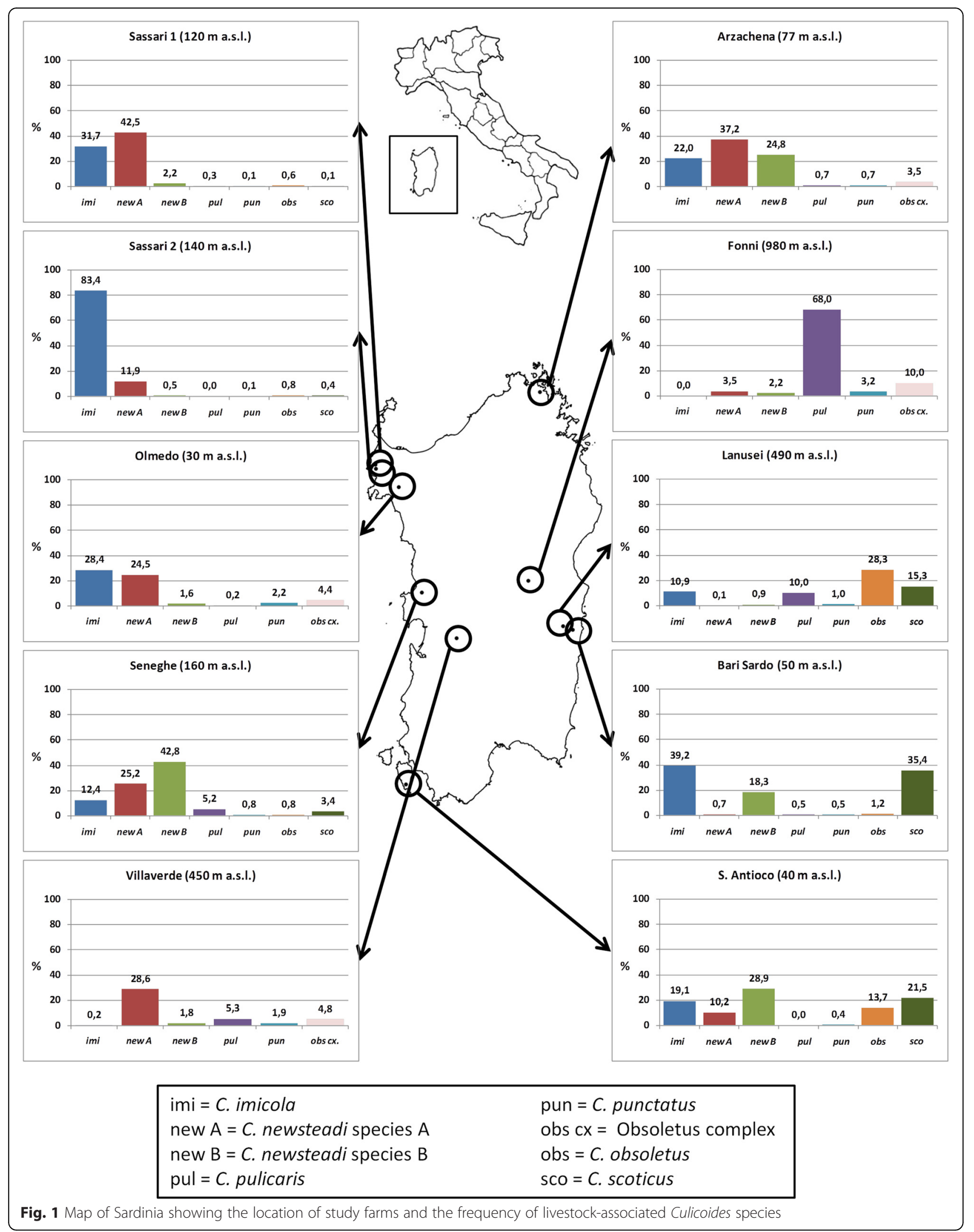


Fox et al. Parasites \& Vectors (2016) 9:440

Page 8 of 13
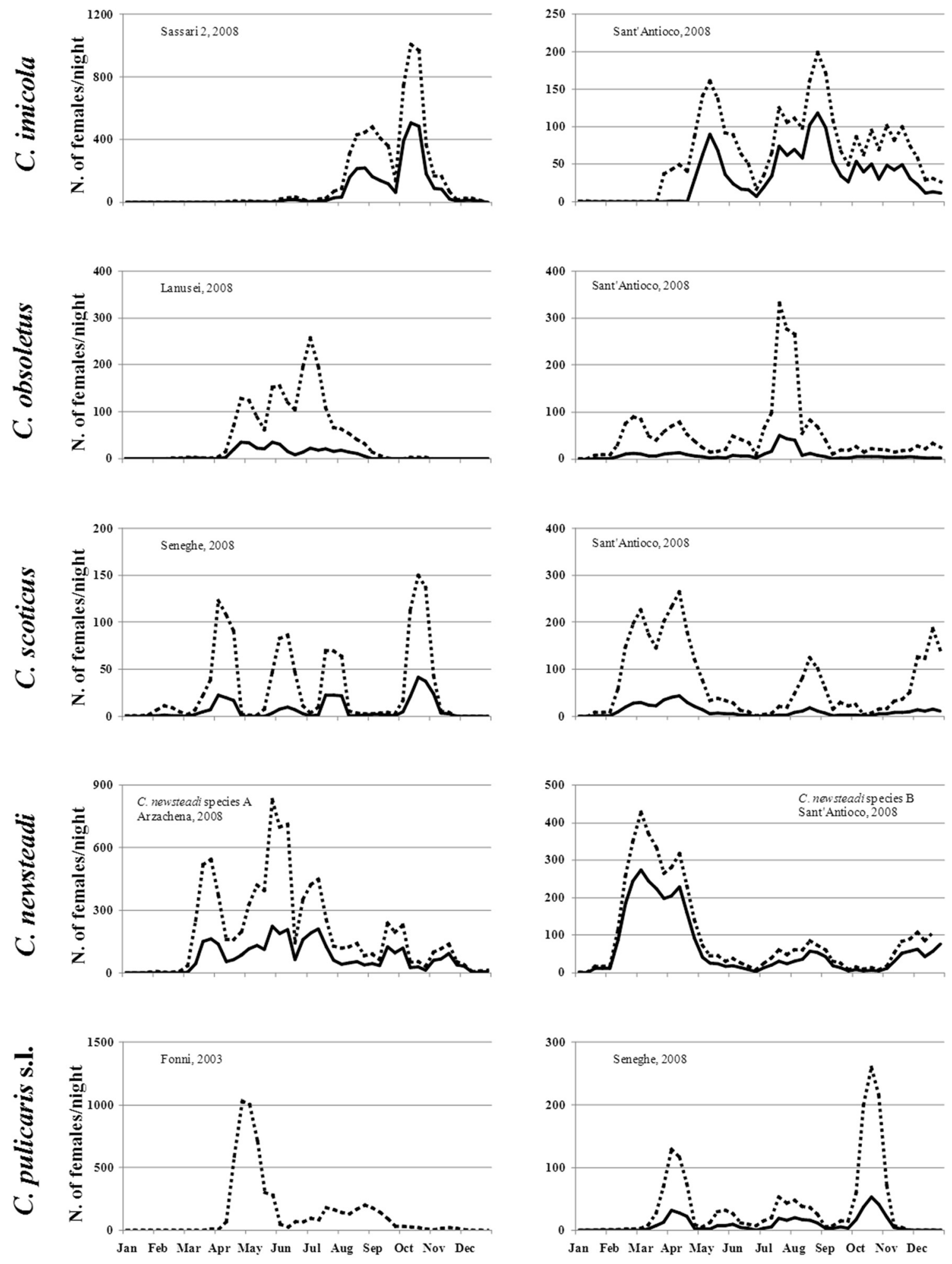

Total females

Parous females

Fig. 2 Seasonal abundance pattern of Culicoides midges in representative farms selected on the basis of the highest catches of each species and comparing a Northern and a Southern location. Dashed lines represent the nightly number of light-trapped females; solid lines depict the nightly number of porous females 
Table 3 RT-qPCR analyses of BTV-1 on Culicoides parous females collected in April-July 2013 in Bari Sardo

\begin{tabular}{lllll}
\hline Species & $\begin{array}{l}\text { No. of } \\
\text { pools } \\
\text { tested }\end{array}$ & $\begin{array}{l}\text { No. of pools with } \\
\text { Ct values }<25\end{array}$ & $\begin{array}{l}\text { No. of pools with } \\
\text { Ct values 25-30 }\end{array}$ & $\begin{array}{l}\text { No. of pools } \\
\text { with Ct values } \\
31-40\end{array}$ \\
\hline C. imicola & 52 & 5 & 6 & 1 \\
C. obsoletus & 2 & 0 & 1 & 0 \\
C. scoticus & 24 & 4 & 7 & 2 \\
$\begin{array}{l}\text { C. newsteadi } \\
\text { species A }\end{array}$ & 46 & 5 & 11 & 5 \\
$\begin{array}{l}\text { C. newsteadi } \\
\text { species B }\end{array}$ & 32 & 3 & & 2 \\
$\begin{array}{l}\text { C. pulicaris } \\
\text { (s.str.) }\end{array}$ & 1 & 0 & 6 & \\
C. punctatus & 6 & 0 & 1 & 0 \\
\hline
\end{tabular}

highest MIR value of 0.058 , while the lowest rate was that for C. imicola (0.023). C. newsteadi species A and species $B$ showed intermediate values (Table 5).

\section{BTV infection prevalence in Culicoides vectors over the year}

Retrospective analyses on virus infection were carried out on ethanol-stored parous females of different Culicoides vectors, collected monthly, in Sassari-1 farm during a major BTV-2 epidemic in 2001. In this farm, C. newsteadi species A (95\% of the Newsteadi complex) was captured throughout the year, with higher abundance in spring, and represented the most prevalent species, followed by C. imicola, captured from April and reaching the population peak in September. The Obsoletus complex, showed a lower population density and included mainly C. obsoletus (85\%) (Fig. 3).

RNA virus was detected and quantified by RT-qPCR in the insect body of the two Newsteadi complex species, and of C. imicola and C. obsoletus. BTV-2 positive pools (Ct values $<30$ ) of $C$. obsoletus and $C$. newsteadi species A were detected during the winter-spring months and sporadically in summer, whereas C. imicola pools showed virus positivity only from September to November (Fig. 3).

Table 4 RT-qPCR analyses targeting BTV-1 in different body regions of Culicoides parous females collected in May-July 2013 in Bari Sardo

\begin{tabular}{lllll}
\hline Species & $\begin{array}{l}\text { No. of } \\
\text { pools }\end{array}$ & $\begin{array}{l}\text { No. of } \\
\text { positive } \\
\text { pools }\end{array}$ & \multicolumn{2}{l}{ qPCR Ct values } \\
\cline { 5 - 6 } & 4 & 1 & $>40$ & 24.25 \\
\hline C. imicola & 4 & 2 & 24.37 & 26.15 \\
C. scoticus & & & $>40$ & 27.20 \\
C. newsteadi species A & 4 & 1 & 28.13 & 26.70 \\
C. newsteadi species B & 4 & 1 & $>40$ & 26.20 \\
C. obsoletus & 2 & 1 & $>40$ & 25.47 \\
\hline
\end{tabular}

Table 5 Minimum Infection Rate $(M I R)^{a}$ in parous females of Culicoides vectors from Bari Sardo

\begin{tabular}{lcccccc}
\hline Species & $\begin{array}{l}\text { Infection } \\
\text { Rate }\end{array}$ & $\begin{array}{l}\text { Lower } \\
\text { Limit }\end{array}$ & $\begin{array}{l}\text { Upper } \\
\text { Limit }\end{array}$ & $\begin{array}{l}\text { No. of } \\
\text { pools }\end{array}$ & $\begin{array}{l}\text { No. of } \\
\text { positive } \\
\text { pools }\end{array}$ & $\begin{array}{l}\text { No. of } \\
\text { individuals }\end{array}$ \\
\hline C. imicola & 0.023 & 0.012 & 0.040 & 52 & 11 & 520 \\
C. scoticus & 0.058 & 0.031 & 0.101 & 24 & 11 & 240 \\
$\begin{array}{l}\text { C. newsteadi } \\
\text { species A }\end{array}$ & 0.041 & 0.025 & 0.066 & 46 & 16 & 460 \\
$\begin{array}{l}\text { C. newsteadi } \\
\text { species B }\end{array}$ & 0.032 & 0.016 & 0.058 & 32 & 9 & 320 \\
$\begin{array}{l}\text { a MIR= number of positive pools/total specimens tested, assuming only one } \\
\text { infected individual midge per positive pool [51] }\end{array}$
\end{tabular}

\section{Discussion}

European species of livestock-associated Culicoides biting midges involved in BTV transmission and identified in our study include C. imicola, C. obsoletus, C. scoticus, C. pulicaris, C. punctatus and two species of the Newsteadi complex. Other potential vectors, such as $C$. chiopterus and C. dewulfi, were never detected in Sardinia [28]. The Newsteadi complex adults were the most frequent and abundant in the majority of the farms, representing around half the total number of collected midges. The predominance of this cryptic species complex, was observed in previous studies conducted in the two adjacent Mediterranean islands, Sardinia [28] and Corsica [53]. Both C. newsteadi species A and B, identified by molecular analysis and wing pattern, were collected in all study farms, but species A generally dominated in Northern Sardinia while species B usually prevailed in the central-southern part of the island (Fig. 1). Culicoides imicola, the second most abundant species, was more frequent near the coast while its population density progressively decreased with altitude, due to a relatively poor tolerance to lower temperatures [54]. This is consistent with the well-documented distribution in Sardinia $[55,56]$ and as described by specific mathematical models $[57,58]$. However, its distribution at farm-level can only be predicted by considering the availability of appropriate breeding sites, that are represented by moist soil patches surrounding leaking animal drinking troughs and feces-contaminated pond margins [26]. Furthermore, the normally extremely dry Mediterranean conditions should be taken into consideration, as they may cause a shrinkage in the availability of these anthropogenic breeding sites in summer, as demonstrated by a previous study in northern Sardinia, where C. imicola larval foci were found only in 41 of more than 100 sampled potential sites [59]. The Obsoletus complex, including C. obsoletus (s.str.) and C. scoticus, represented $17 \%$ of the total Culicoides midges collected in Sardinia and was detected in all farms with a general prevalence of $C$. scoticus. The females of this complex were identified by morphometric measures of genitalia combined with molecular analyses. Although measurements of spermathecae of our samples were generally higher in 


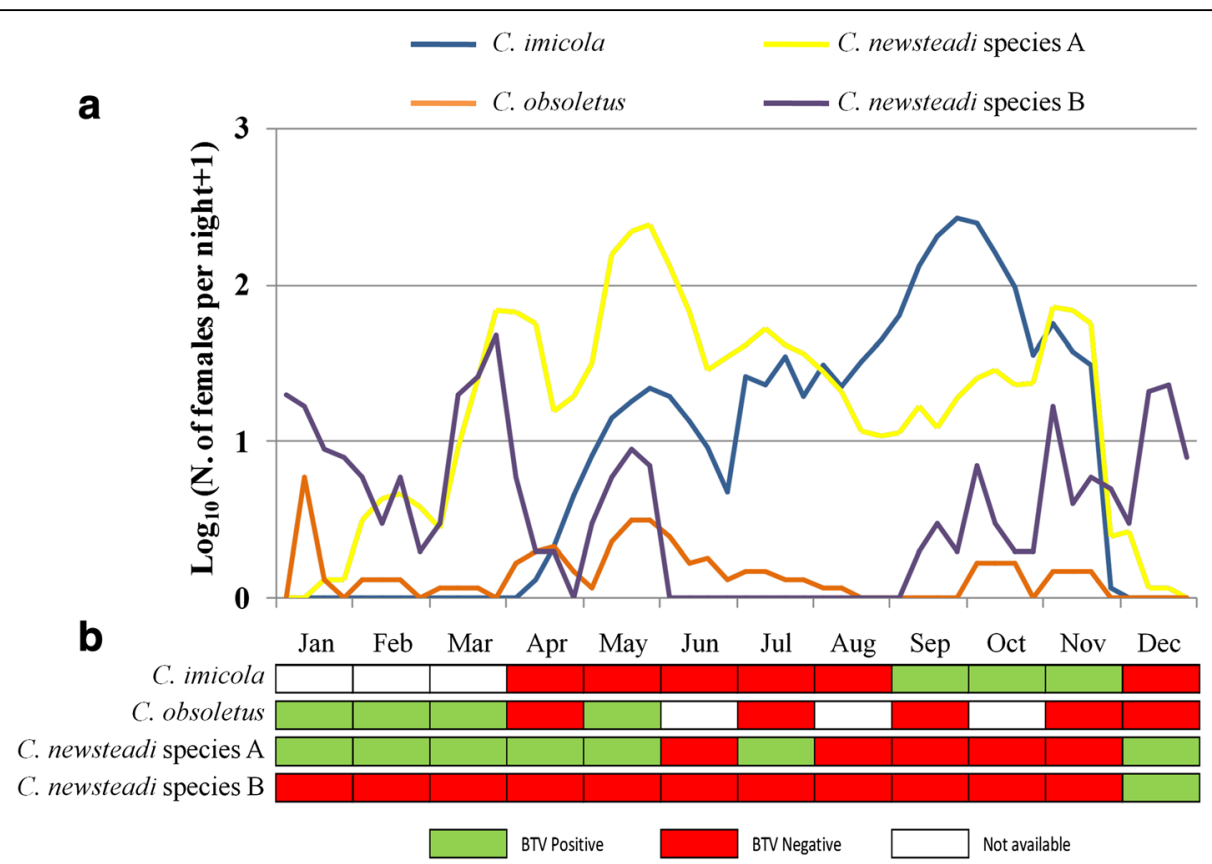

Fig. 3 Culicoides abundance and BTV prevalence in Sassari-1 during 2001. a) seasonal patterns of abundance of parous females and b) BTV-2 infection prevalence per month

comparison with samples reported in France [39] and other European countries [40], these values did not exhibit overlapping ranges, thus confirming their reliability for the morphometric identification of the two species, allowing a significant laboratory cost saving.

Higher abundance was associated with cow farms along the coast, probably due to the composted cow manure accumulating in cattle holding and spread on cropping lands and pastures. Although $C$. obsoletus and $C$. scoticus are able to breed in a great variety of habitats, dung heaps and cow pats are emerging as their most important farm development substrates in Germany [60]. Culicoides pulicaris and C. punctatus were generally collected in smaller amounts and a higher abundance of the first species was especially recorded in farms at higher altitudes.

Culicoides imicola is a multivoltine species, having several generations per year regulated by temperature and other climatic factors [61]. In Sardinia, adults were collected from April and their density gradually grew to reach a plateau between August and November [28, 62]. For other Palaearctic Culicoides vectors, including Obsoletus and Newsteadi complex species that produce 3-4 generations per year [26], parous females were collected from February until the end of the year, with higher density in spring, summer and autumn.

The significant viral RNA titers detected by qRT-PCR in the body of parous females of C. imicola, C. obsoletus, C. scoticus and C. newsteadi species A and B, support their vector competence during BTV-2 and BTV-1 epidemics in Sardinia. As a confirmation of the ability of the virus to replicate inside females of these species, meaningful high virus genome loads $(\mathrm{Ct}$ values $<25)$ were found in the thorax, where salivary glands are located, and exceptionally in the head. BTV infection prevalence was also observed in few parous female pools of C. obsoletus, C. pulicaris and C. punctatus, indicating their possible implication in virus transmission in Sardinia. This study confirmed the ability of different Culicoides species to harbor both BTV-1 and BTV-2 serotypes, but specific experiments are needed to assess possible differences in their susceptibility levels.

Among BTV-positive midge species collected in this study, C. imicola, C. obsoletus, and C. scoticus are recognized as proven vectors in Europe, as supported by repeated virus isolation from field-collected females $[16,17]$ and by laboratory infection studies demonstrating their oral susceptibility to the virus [22-24]. Culicoides newsteadi has been regarded as a potential vector since few intrathoracically-inoculated females from Israel sustained virus replication in the laboratory [63]. The high virus genome loads we found in thorax and full body samples of C. newsteadi species A and B, supported the full BTV dissemination in field-collected parous females, which corroborates the results of other investigations in Italy [31]. While the high amount of viral RNA inside the insect body can be evidence of insect competence, this should be confirmed by the isolation of viable virus particles and proper infection 
studies in the laboratory. However, Newsteadi complex species should undoubtedly be implicated in virus transmission among animals because of their abundance in internal areas of Sardinia, where C. imicola was only sporadically collected. In addition, their winter-spring activity period makes $C$. newsteadi species A and $B$ the main candidates for virus overwintering.

The estimated prevalence of BTV-1 infection in field-collected parous females of most abundant vector species in our study was comparable to previous infection rate determinations in Sardinia and other Italian regions [31]. Higher Minimum Infection Rate (MIR) values were associated to Obsoletus and Newsteadi complex species, indicating a probably higher susceptibility of the Obsoletus complex in comparison to C. imicola, which is consistent with laboratory infection studies in England [24]. However, when infection rate calculations are based on light trap collected females, as in our study, a possible underestimation of virus prevalence may result from repellent effects of light against infected vectors [64].

On the other hand, neither the field infection rate determination nor the evaluation of vector competence represent the actual potential of vector populations to transmit the disease among animals. This could more appropriately be estimated through the vector capacity, defined as the average number of infective bites per host per day [65]. Vector capacity depends on either vector competence and various biological traits of the vector such as life history parameters, gonotrophic cycle length, longevity, proportion of blood meals, and host biting rate [32]. Even though the contribution of these parameters is still scarcely investigated on European midge vectors, the actual role of these species during BT epidemics in Sardinia can be evaluated taking into account the main factors affecting the host biting rate, like species distribution, abundance and phenology. Field abundance and host preference of a species can compensate for its limited vector competence and infection rate, as confirmed by studies in Australia where a more important vector role was associated with the relatively inefficient but abundant $C$. brevitarsis, in respect to the more efficient but less abundant $C$. fulvus [66].

In Sardinia, C. imicola plays a main role in BTV transmission along coastal areas where this species is significantly abundant, as documented by extraordinary capture levels in certain farms where more than 200,000 midges per night were collected by a single trap. This multivoltine and thermophilic species was rarely captured during the first half of the year and peaked in summer-autumn in conjunction with BT epidemics. Both in the same areas and inland, an augmentative vector role can be attributed to the more abundant $C$. newsteadi species $\mathrm{A}$ and $\mathrm{B}$ that were found all over the year. An additional contribution to BT spread along the coast and inland may derive from populations of other vectors like C. obsoletus, C. scoticus and $C$. pulicaris, that can reach high local abundance, especially in cow farms.

The BT epidemic waves in Sardinia normally lasted 2-3 years, and achieved an end as a consequence of natural animal immunization and vaccination campaigns. Infection continuity, over the years, revealed obvious virus overwintering. In this context, parous females of Newsteadi and Obsoletus complex species associated with high viral loads were collected during winter-spring in diverse areas where these species could be directly implied in virus overwintering [28, 33]. Proposed potential mechanisms for the interseasonal maintenance of BTV in temperate areas include: (i) virus transovarial transmission from parent to offspring insect vectors; (ii) increased duration of ruminant livestock infection; (iii) prolonged Culicoides adult lifespan following the active virus transmission period; (iv) ongoing and slow/low-level cycle of infection and transmission between ruminants and midges over the interseasonal period [67-69]. While we cannot exclude more mechanisms may coexist in the same area, the demonstration that Culicoides vectors with high viral load are found in winter-spring in conjunction with low seroconvertion rate in animals in Sardinia, would support a continuous cycle of infection and transmission between ruminants and midge vectors.

\section{Conclusions}

Based on this study and on previous knowledge on distribution and abundance of Culicoides species, Bluetongue in Sardinia and probably in other Mediterranean regions, is likely to be transmitted by multiple vectors, which ensures virus spread in areas characterized by different environmental and climatic conditions. In addition, different species can be involved in virus overwintering, thus contributing to endemicity of this disease that almost continuously appeared during the last 15 years in Sardinia and the neighboring Mediterranean regions.

\section{Abbreviations \\ asl, above sea level; BT, Bluetongue; BTV, bluetongue virus; COI, mithocondrial cytochrome oxidase $\mathrm{C}$ subunit I; ITS2 rDNA, ribosomal internal transcribed spacer 2; MIR, minimum infection rate; RT-qPCR, Real-time Quantitative Reverse Transcription-Polymerase Chain Reaction; s.l., sensu lato; s.str., sensu stricto}

\section{Acknowledgements}

Not applicable.

\section{Funding}

This study was financially supported by Regione Autonoma della Sardegna L.R. 7 (Project 2012: Nuovi approcci alla gestione eco-compatibile di parassiti degli allevamenti zootecnici). 


\section{Availability of data and materials}

Essential data supporting the conclusions of this article are included within the main text and its additional files.

\section{Authors' contributions}

$C F, G D$ and $L R$ conceived and designed the experiments. CF performed field experiments and insect identifications. GF and MGM performed molecular analyses. CF, GD and LR analyzed the data. GD, GS and LR contributed reagents/materials/analysis tools. CF, GD and LR wrote the article. All authors read and approved the final manuscript.

\section{Competing interests}

The authors declare that they have no competing interests.

\section{Consent for publication}

Not applicable.

\section{Ethics approval and consent to participate}

Not applicable.

\section{Author details}

'Dipartimento di Agraria, University of Sassari, Via E. De Nicola, Sassari, Italy. ${ }^{2}$ Istituto Zooprofilattico Sperimentale della Sardegna, Via Duca degli Abruzzi 8, Sassari, Italy.

Received: 8 March 2016 Accepted: 28 July 2016

\section{Published online: 09 August 2016}

\section{References}

1. Borkent A. World species of biting midge (Diptera: Ceratopogonidae). Salmon Arm: Royal British Columbia Museum, American Museum of Natural History and Instituto Nacional de Biodiversidad; 2014. http://wwx.inhs.illinois.edu/files/ 9913/9144/3328/CeratopogonidaeCatalog.pdf. Accessed 15 Nov 2015.

2. Mellor PS, Boorman J, Baylis M. Culicoides biting midges: their role as arbovirus vectors. Annu Rev Entomol. 2000:45:307-40.

3. Maan NS, Maan S, Belaganhalli MN, Ostlund EN, Johnson DJ, Nomikou K, et al. Identification and differentiation of the twenty-six bluetongue virus serotypes by RT-PCR amplification of the serotype-specific genome segment 2. PLoS One. 2012;7(2):e32601.

4. Zientara S, Sailleau C, Viarouge C, Hoper D, Beer M, Jenckel M, et al. Novel bluetongue virus in goats, Corsica, France, 2014. Emerg Infect Dis. 2014;20(12):2123-25.

5. Wilson AJ, Mellor PS. Bluetongue in Europe: past, present and future. Phil Trans R Soc B. 2009;364:2669-81.

6. Batten C, Darpel K, Henstock M, Fay P, Veronesi E, Gubbins S, et al. Evidence for transmission of bluetongue virus serotype 26 through direct contact. PLoS One. 2014;9(5):e96049.

7. Mellor PS. Replication of arboviruses in insect vectors. J Comp Pathol. 2000;123:231-47.

8. Tabachnick WJ. Culicoides variipennis and bluetongue-virus epidemiology in the United States. Annu Rev Entomol. 1996;41:23-43.

9. Carpenter S, Wilson A, Barber J, Veronesi E, Mellor P, Venter G, et al. Temperature dependence of the extrinsic incubation period of Orbiviruses in Culicoides biting midges. PLoS One. 2011;6:e27987.

10. Meiswinkel R, Gomulski LM, Delécolle J-C, Goffreddo M, Gasperi G. The taxonomy of Culicoides vector complexes-unfinished business. Vet Ital. 2004; 40(3):151-9.

11. Carpenter S, Veronesi E, Mullens B, Venter G. Vector competence of Culicoides for arboviruses: three major periods of research, their influence on current studies and future directions. Rev Sci Tech Off Int Epiz. 2015;34(1):97-112.

12. Koenradt CJM, Balenghien T, Carpenter S, Ducheyne E, Elbers ARW, Fife M, et al. Bluetongue, Schmallenberg-what is next? Culicoides-borne viral diseases in the 21st Century. BMC Vet Res. 2014;10:77.

13. Hoffmann B, Bauer B, Bauer C, Batza HJ, Beer M, Clausen P-H, et al. Monitoring of putative vectors of bluetongue virus serotype 8 , Germany. Emerg Infect Dis. 2009;15:1481-84.

14. Veronesi E, Antony F, Gubbins S, Golding N, Blackwell A, Mertens PPC, et al. Measurement of the infection and dissemination of Bluetongue virus in Culicoides biting midges using a semi-quantitative RT-PCR assay and isolation of infectious virus. PLoS One. 2013;8:e70800.
15. Caracappa S, Torina A, Guercio A, Vitale F, Calabro A, Purpari G, et al. Identification of a novel bluetongue virus vector species of Culicoides in Sicily. Vet Rec. 2003;19:71-4.

16. De Liberato C, Scavia G, Lorenzetti R, Scaramozzino P, Amaddeo D, Cardati $\mathrm{G}$, et al. Identification of Culicoides obsoletus (Diptera: Ceratopogonidae) as a vector of bluetongue virus in central Italy. Vet Rec. 2005;156:301-4.

17. Savini G, Goffredo M, Monaco F, Di Gennaro A, Cafiero MA, Baldi P, et al. Bluetongue virus isolations from midges belonging to the Obsoletus complex (Culicoides, Diptera: Ceratopogonidae) in Italy. Vet Rec. 2005;157:133-9.

18. Meiswinkel R, Van Run P, Leijs P, Goffredo M. Potential new Culicoides vector of bluetongue virus in northern Europe. Vet Rec. 2007;161:564-5.

19. Dijkstra E, van der Ven IJK, Holzel DR, Van Rijn PA, Meiswinkel R. Culicoides chiopterus as a potential vector of bluetongue virus in Europe. Vet Rec. 2008;162:422.

20. Vanbinst $T$, Vandenbussche $F$, Vandemeulebroucke $E$, De Leeuw I, Deblauwe I, De Deken G, et al. Bluetongue virus detection by RealTime RT-PCR in Culicoides captured during the 2006 epizootic in Belgium and development of an internal control. Transbound Emerg Dis. 2009;56:170-7.

21. Romòn P, Hiquera M, Delécolle J-C, Baldet T, Aduriz G, Goldarazena A. Phenology and attraction of potential Culicoides vectors of bluetongue virus in Basque Country (northern Spain). Vet Parasitol. 2012;186(3-4):415-24.

22. Del Rio LR, Miranda MA, Paredes-Esquivel C, Lucientes J, Calvete C, Estrada $R$, et al. Recovery rates of bluetongue virus serotypes 1, 2, 4 and 8 Spanish strains from orally infected Culicoides imicola in South Africa. Med Vet Entomol. 2012;26(2):162-7.

23. Carpenter S, Lunt HL, Arav D, Venter GJ, Mellor PS. Oral susceptibility to bluetongue virus of Culicoides (Diptera: Ceratopogonidae) from the United Kingdom. J Med Entomol. 2006;43:73-8.

24. Carpenter S, McArthur C, Selby R, Ward R, Nolan DV, Mordue Luntz AJ. Experimental infection studies of UK Culicoides species midges with bluetongue virus serotypes 8 and 9. Vet Rec. 2008;163:589-92.

25. Purse BV, Carpenter S, Venter GJ, Bellis G, Mullens BA. Bionomics of temperate and tropical Culicoides midges: knowledge gaps and consequences for transmission of Culicoides-borne viruses. Annu Rev Entomol. 2015;60:373-92.

26. Foxi C, Delrio G. Larval habitats and seasonal abundance of Culicoides biting midges found in association with sheep in northern Sardinia, Italy. Med Vet Entomol. 2010;24:199-209.

27. Bluetongue in Italy. In: European Commission, Animal Health Regulatory Committee presentations. http://ec.europa.eu/food/animals/docs/reg-com_ ahw_20141103_pres_ah_bluetongue-italy.pdf.

28. Foxi C, Pinna M, Sarto I, Monteys V, Delrio G. An updated checklist of the Culicoides Latreille (Diptera: Ceratopogonidae) of Sardinia (Italy), and seasonality in proven and potential vectors for bluetongue virus (BTV). Proc Entomol Soc Wash. 2011;113(4):403-16.

29. Gomulski LM, Meiswinkel R, Delécolle JC, Goffredo M, Gasperi G. Phylogeny of the subgenus Culicoides and related species in Italy, inferred from internal transcribed spacer 2 ribosomal DNA sequences. Med Vet Entomol. 2006;20:229-38.

30. Foxi C, Delrio G, Falchi G, Marche MG, Ruiu L. Culicoides (Diptera: Ceratopogonidae) vettori del virus della Bluetongue in Sardegna. In: XXIV Congresso Nazionale Italiano di Entomologia. Accademia Nazionale Italiana di Entomologia. 2014. p. 87-8. http://www.accademiaentomologia.it/pdf/ XXIV Convegno Nazionale Italiano di Entomologia_E book comunicazioni orali.pdf.

31. Goffredo M, Catalani M, Federici V, Portanti O, Marini V, Mancini G, et al. Vector species of Culicoides midges implicated in the 2012-2014 Bluetongue epidemics in Italy. Vet Ital. 2015;51(2):131-8.

32. Mullens BA, Gerry AC, Lysyk TJ, Schmidtmann ET. Environmental effects on vector competence and virogenesis of bluetongue virus in Culicoides: interpreting laboratory data in a field context. Vet Ital. 2004;40(3):160-6.

33. Pili E, Carcangiu L, Oppo M, Marchi A. Genetic structure and population dynamics of the biting midge Culicoides obsoletus and Culicoides scoticus: implications for the transmission and maintenance of bluetongue. Med Vet Entomol. 2010;24:441-8.

34. Kremer M. Contribution à l'étude du genre Culicoides Latreille particulièrement en France. Encycl Ent A. 1965;39:1-299.

35. Delécolle JC. Nouvelle contribution à l'étude systématique et iconographique des espèces du genre Culicoides (Diptera: Ceratopogonidae) 
du Nord - Est de la France. Thesis/Dissertation: Université Louis Pasteur de Strasbourg (France); 1988.

36. Glukhova VM. Culicoides (Diptera: Ceratopogonidae) of Russian and adjacent lands. Intern J Dipterolog Res (Riga). 2005;16:3-75.

37. Gomulski LM, Meiswinkel MR, Delecolle JC, Goffredo M, Gasperi G. Phylogenetic relationships of the subgenus Avaritia Fox, 1955 including Culicoides obsoletus (Diptera: Ceratopogonidae) in Italy based on internal transcribed spacer 2 ribosomal DNA sequences. Syst Entomol. 2005;10:619-31.

38. Nolan DV, Carpenter S, Barber J, Mellor PS, Dallas JF, Mordue Luntz AJ, et al. Rapid diagnostic PCR assays for members of the Culicoides obsoletus and Culicoides pulicaris species complexes, implicated vectors of bluetongue virus in Europe. Vet Microbiol. 2007;124:82-94.

39. Augot D, Sauvage F, Jouet D, Simphal E, Veuille M, Couloux A, et al. Discrimination of Culicoides obsoletus and Culicoides scoticus, potential bluetongue vectors, by morphometrical and mitochondrial cytochrome oxidase subunit I analysis. Infec Gen Evol. 2010;10:629-37.

40. Kluiters G, Pagès N, Carpenter S, Gardès L, Guis H, Baylis M, et al. Morphometric discrimination of two sympatric sibling species in the Palaearctic region, Culicoides obsoletus Meigen and C. scoticus Downes \& Kettle (Diptera; Ceratopogonidae), vectors of bluetongue and Schmallenberg viruses. Parasit Vectors. 2016;9:262.

41. Pagès N, Muñoz-Muñoz F, Talavera S, Sarto V, Lorca C, Núñez JI. Identification of cryptic species of Culicoides (Diptera: Ceratopogonidae) in the subgenus Culicoides and development of species-specific PCR assays based on barcode regions. Vet Parasitol. 2009;165:298-310.

42. Lassen SB, Nielsen SA. Skovg ard H, Kristensen M. Molecular differentiation of Culicoides biting midges (Diptera: Ceratopogonidae) from the subgenus Culicoides Latreille in Denmark. Parasitol Res. 2012;110:1765-71.

43. Sarvasova A, Kocisova A, Halan M, Delecolle J-C, Mathieu B. Morphological and molecular analysis of the genus Culicoides (Diptera: Ceratopogonidae) in Slovakia with five new records. Zootaxa. 2014;3872(5):541-60.

44. Nielsen SA, Kristensen M. Delineation of Culicoides species by morphology and barcode exemplified by three new species of the subgenus Culicoides (Diptera: Ceratopogonidae) from Scandinavia. Parasit Vectors. 2015;8:151.

45. Ramilo D, Garros C, Mathieu B, Benedet C, Allène X, Silva E, et al. Description of Culicoides paradoxalis sp. nov. from France and Portugal (Diptera: Ceratopogonidae). Zootaxa. 2013;3745(2):243-56.

46. Dyce AL. The recognition of nulliparous and parous Culicoides (Diptera: (eratopogonidae) without dissection. J Aust Entomol Soc. 1969;8:11-5.

47. Veronesi E, Mertens PPC, Shaw AE, Brownlie J, Mellor PS, Carpenter ST. Quantifying Bluetongue virus in adult Culicoides biting midges (Diptera: Ceratopogonidae). J Med Entomol. 2008;45(1):129-32.

48. Shaw AE, Monaghan P, Alpar HO, Anthony S, Darpel KE, Batten CA, et al. Development and initial evaluation of a real-time RT-PCR assay to detect bluetongue virus genome segment 1. J Vir Meth. 2007;145:115-26.

49. Lorusso A, Sghaier S, Carvelli A, Di Gennaro A, Leone A, Marini V, et al. Bluetongue virus serotypes 1 and 4 in Sardinia during autumn 2012: new incursions or re-infection with old strains? Infect Genet Evol. 2013;19:81-7.

50. R Core Team. R: A language and environment for statistical computing. Vienna: R Foundation for Statistical Computing; 2013. URL http://www.R-project.org/. ISBN 3-900051-07-0.

51. Biggerstaff BJ. PooledInfRate, Version 4.0: a MicrosoftR Office ExcelC Add-In to Compute Prevalence Estimates from Pooled Samples. Fort Collins: Centers for Disease Control and Prevention; 2009. available at: http://www.cdc.gov/ncidod/dvbid/westnile/software.htm.

52. Searle KR, Blackwell A, Falconer D, Sullivan M, Butler A, Purse BV. Identifying environmental drivers of insect phenology across space and time: Culicoides in Scotland as a case study. Bull Entomol Res. 2013; 103(2):155-70

53. Baldet T, Délecolle JC, Mathieu B, de La Rocque S, Roger F. Entomological surveillance of bluetongue in France. Vet Ital. 2004;40(3):226-31.

54. Verhoef FA, Venter GJ, Weldon CW. Thermal limits of two biting midges, Culicoides imicola Kieffer and C. bolitinos Meiswinkel (Diptera: Ceratopogonidae). Parasit Vectors. 2014;7:384.

55. Pili E, Ciucce' S, Culurgioni J, Figus V, Pinna G, Marchi A. Distribution and abundance of bluetongue vectors in Sardinia: comparison of field data with prediction maps. J Vet Med B. 2006;53(7):312-6.

56. Conte A, Goffredo M, Ippoliti C, Meiswinkel R. Influence of biotic and abiotic factors on the distribution and abundance of Culicoides imicola and the Obsoletus Complex in Italy. Vet Parasitol. 2007;150:333-44.
57. Rigot T, Conte A, Goffredo M, Ducheyne E, Hendricks G, Gilbert M Predicting the spatio-temporal distribution of Culicoides imicola in Sardinia using a discrete-time population model. Parasit Vectors. 2012;5:270.

58. Ippoliti C, Gilbert M, Vanhuysse S, Goffredo M, Satta G, Wolff E, et al. Can landscape metrics help determine the Culicoides imicola distribution in Italy? Geospat Health. 2013;8(1):267-77.

59. Delrio G, Deliperi S, Foxi C, Pantaleoni RA, Piras S. Osservazioni in Sardegna sulla dinamica di popolazione di Culicoides imicola Kieffer vettore della bluetongue. In: Atti XIX, editor. Congresso Nazionale Italiano di Entomologia. Sondrio: Litografia Tipografia POLARIS; 2004. p. 1089-94.

60. Steinke S, Luhken R, Balczun C, Kiel E. Emergence of Culicoides obsoletus group species from farm-associated habitats in Germany. Med Vet Entomol. 2016. doi:10.1111/mve.12159.

61. Braverman Y, Linley JR. Parity and voltinism of several Culicoides spp. (Diptera: Ceratopogonidae) in Israel, as determined by two trapping methods. J Med Entomol. 1988;25:121-6.

62. Goffredo M, Conte A, Cocciolito R, Meiswinkel R. Distribuzione e abbondanza di Culicoides in Italia. Vet Ital. 2003;39:22-32.

63. Mellor PS, Jennings DM, Braverman Y, Boorman J. Infection of Israeli Culicoides with African horse sickeness, Bluetongue and Akabane viruses. Acta Virol. 1981;25:401-7.

64. McDermott EG, Mayo CE, Gerry AC, Laudier D, MacLachlan NJ, Mullens BA. Bluetongue virus infection creates light averse Culicoides vectors and serious errors in transmission risk estimates. Parasit Vectors. 2015;8:460.

65. Dye $\mathrm{C}$. The analysis of parasite transmission by bloodsucking insects. Annu Rev Entomol. 1992;37:1-19.

66. Standfast HA, Dyce A, Muller MJ. Vectors of bluetongue in Australia. Laboratory infections of Culicoides debilipalpis and C. stellifer (Diptera: Ceratopogonidae) with bluetongue virus. In: Barber TL, Jochim MM, editors. Bluetongue and related orbiviruses. Proc. of an International Symposium. New York: Alan R. Liss; 1995. p. 177-86.

67. Nevill EM. Cattle and Culicoides biting midges as possible overwintering hosts of bluetongue virus. Onderstepoort J Vet Res. 1971;38:65-71.

68. Wilson A, Darpel K, Mellor PS. Where does bluetongue virus sleep in the winter? PLoS Biol. 2008;6:e210.

69. Mayo CE, Mullens BA, Reisen WK, Osborne CJ, Gibbs EPJ, Gardner IA, et al. Seasonal and interseasonal dynamics of Bluetongue virus infection of dairy cattle and Culicoides midges in Northern California - Implications for virus overwintering in temperate zones. PLoS One. 2014;9(9):e106975.

\section{Submit your next manuscript to BioMed Central and we will help you at every step:}

- We accept pre-submission inquiries

- Our selector tool helps you to find the most relevant journal

- We provide round the clock customer support

- Convenient online submission

- Thorough peer review

- Inclusion in PubMed and all major indexing services

- Maximum visibility for your research

Submit your manuscript at www.biomedcentral.com/submit
Ciomed Central 